\title{
THE IMPLEMENTATION OF WORD WALL STRATEGY IN TEACHING WRITING DESCRIPTIVE TEXT
}

\author{
Yani Darliani ${ }^{1}$ Cica Farida Agustina ${ }^{2}$ \\ ${ }^{1,2}$ STKIP Pasundan, Indonesia \\ Email: yanidarliani@gmail.com
}

\begin{abstract}
Sometimes students experience writing problems, attempt to understand the text and get confused to begin describing because they lack vocabulary and concept. The study was directed at finding out the Word Wall approach introduced in teaching descriptive text to high school vocational learners and finding answers for learners in learning descriptive text to implement the Word Wall approach. The study was carried out at one of Bandung's vocational high schools. In this study, the descriptive qualitative method was used. The research participants are a first-grade teacher and five students. The information was acquired as the study tool by observation and interview. Word wall approach is one of the strategies that can be used in the learning process of teaching. Word Wall approach was a strategy consisting of a group of phrases that placed a distinct background color on the wall that corresponds to a distinct curricular goal. The teacher provides learners with important phrases or clues to readily create their thoughts. The outcome demonstrates that all respondents responded positively to the approach of Word Wall. Implementing Word Wall approach has been useful in teaching for high school vocational learners and makes writing descriptive text enjoyable for learning.
\end{abstract}

Keywords: Writing, descriptive text, word wall

\section{INTRODUCTION}

In Indonesian Vocational High School, English as a foreign language is a mandatory subject. English is used as an oral and written means of communication consisting of four competencies: listening, talking, reading, and writing. Writing is one of those abilities to enhance English. According to Nunan (2003) quoted in (Sari \& Fahri, 2016), writing is not only an activity of generating words in paragraphs or essays, but it also includes many elements. To generate a communicative written text, writing needs a strong grammar, vocabulary and other elements in written form. A writer will automatically write a text into a phrase when writing.

Students will learn a range of texts in Vocational High Schools such as narrative, descriptive, recount, etc. Descriptive text is a text that describes an object that has generic structure and language characteristics such as individuals, animals or places. Students learning descriptive text anticipated the significance of written functional text or a straightforward brief essay to be expressed. Sometimes in writing, students have difficulty understanding the text and are confused to start describing because they lack vocabulary, they don't understand what to convey and say through writing so it's hard to write.

Sometimes in writing, students have difficulty understanding the text and are confused to start describing because they lack vocabulary, they don't understand what to convey and say through writing so it's hard to write. The teacher needed a plan to solve these issues in order to get the learners experience and thoughts in writing as well as to encourage motivation in writing for the learners. The teacher needs appropriate strategy, 
so students don't feel bored and foster their interest and create self-confidence in writing, particularly when writing descriptive text. Word-wall approach is one of the methods that can be used.

Word wall can be used to be an interactive tool for students during writing and reading. Word Wall will use words categorized by written in capital letters that will be attached to the wall or on the board so the students can see the words. Brabham \& Villaume (2001), Copper \& Kiger (2003) cited in (Sartika, 2017) states, "Word Wall is a collection of high-frequency sight words that are age appropriate, classified into groups or categories, and is located on the wall of a classroom for children to easily see and learn." Through wall word, students can see the words so it helps in remembering words and getting new vocabulary. Huebner \& Bush (1970) cited in (Jasmin \& Schiesl, 2009) states, "The main purpose of a word wall is to help students build sight word recognition so they can recognize them at a glance.

\section{METHOD}

In this study, the research design is descriptive in order to understand how to implement the Word Wall approach in teaching descriptive text writing and the reactions of learners to word wall strategy in teaching descriptive text writing. Descriptive is a design in this research which is only described situation or phenomenon. In this research descriptive used in order to know the implementation of Word Wall strategy in teaching writing descriptive text and students' responses toward Word Wall strategy in teaching writing of descriptive text. According to Burns \& Grove (2003) quoted in (Nurroni, 2013), descriptive study is intended to provide an image of a natural condition. It can be used to explain present practice, judge and create theories as well.

As the main objective of the research is to find the real condition of teaching and learning process classroom, the researcher needs to observe a class of writing. The participant in this research is the teacher who implemented Word Wall strategy in teaching writing descriptive text and five students who are taught writing descriptive text using descriptive text.

The main instrument of this research is observation, through observation, data can be obtained through what is seen and what is heard. Burns (1990) in (Basrowi \& Suwandi, 2008) argued that through observation, researchers can document and reflect systematically on the activities and interactions of research subjects. The aim of observation is to observe the process of teaching English by implementing word wall strategy by watching directly into the class during teaching and learning English. Observation gives real condition that happens in the classroom. In observing the researcher used video recording and field notes to find out word wall strategy implemented in teaching writing descriptive text to Vocational High School students. The observation was conducted three times in one class.

While observation is a way to see all activities that occur naturally both in a group or individual directly, researcher needs another instrument to answer question number two. The researcher used sound recorder to find out word wall strategy implemented in teaching writing descriptive text to Vocational High School students and to find out students' responses toward the implementation of Word Wall strategy in teaching writing of descriptive text. The interview was conducted to the teacher and students. The interview to teacher and students were conducted four times.

A summary or writing field notes describing the condition of the teaching process between teacher and learners during the studies is performed in the evaluation of observational data. Field notes are processed into descriptions of observations of the situation in the classroom, starting with pre-teaching activities, while teaching and post- 
teaching activities. In the interview evaluation by transcribing from interview outcomes. The interview is transcribed or transformed in writing to help learners discover answers to the application of Word Wall approach in writing descriptive text education. Ary et al (2010) cited in (Sarjan \& Mardiana, 2017) state the data analysis can be broken down into four stages; they are Coding, Data Reduction, Data Display, and Drawing Conclusion or Interpretation.

\section{FINDINGS AND DISCUSSION}

\section{Implementation of Word Wall Strategy in Teaching Writing Descriptive Text}

The teacher takes some measures in applying Word Wall approach in teaching descriptive text writing based on classroom observation. Implementation comprises of operations of pre-teaching while teaching operations and activities of post-teaching.

First, the teacher does pre-teaching activities, as follow:

Brainstorming activity is done by asking questions and answer about descriptive text. This activity attracts student attention to learning and also encourages students' prior knowledge.

"Today we are going to learn about descriptive text. What is descriptive text?"

"Describe about something, place, people, animal."

"So, what else in descriptive text?"

"Identification, general introduction"

"What next?"

"Description, detail information"

"Very good, you still remember it. Today we are going to learn describing people. What should you describe about people?

"It can be name, age, name of parent."

Second, the teacher does whilst-teaching activities, as follow:

a. Informs Word Wall strategy in teaching learning.

"For today we are going to learn about descriptive text with Word Wall strategy. Do you know what is Word Wall?"

"Dinding kata"

b. Informs the students about procedure to make Word Wall.

"To make Word Wall you have to put some words and then you have to put in certain place so you are easy to see. So, I want you to stick the words here but you have to categorize and then put on the wall, with Word Wall you may improve your vocabulary.

c. Gives some clues or key words to make Word Wall

"We categorize into Physical Appearance, Character, Action Verb, of course Verb 1 and then Feelings. What is Physical Appearance, Character?"

"Penampilan fisik, sifat"

d. Asks students to make a group and gives some words to each group. The teacher asks students to analyze the words and they should categorize them.

e. Asks students to choose and read some words in Word Wall with the meaning. "Please choose 3 words and then give me also the meaning."

"What is the meaning of guilty?"

"Bersalah" 
"Good. Teenager means?"

"Remaja"

"What is the meaning of of calm? Please be calm..."

"Who wants to say three words and their meanings?"

"Me...me..."

f. Gives a chance to students who has new idea and write word in the Word Wall.

"Who has a new idea?"

Students write some words

Sleep, miss, sing, phobia, firm, handsome, flat nose, genius, humble, run, dance, learn, selfish, skinny, introvert, write, shy, disappointed, tired, jealous, worry, bald.

"Anybody else?"

One by one student wrote some word in Word Wall.

g. Asks students to read and explain about the meaning of new words that written by them according to their idea in the Word Wall.

"What is the meaning of humble, introvert?"

"Rendah hati, pendiam"

"Good job"

"Thanks Miss, amiiinn"

h. Gives students the task to write descriptive text about people and the teacher watches students during writing.

"Only physical information?"

"Not only physical"

"How about famous person, mam?"

"No problem... but you have to know him well."

"Don't be afraid to make mistakes, you can learn from it.."

i. Helps students when they face difficulties, especially regarding new words

"Miss, What is 'mirip' in English?"

"Similar, look alike"

j. Checks their writing then asks student to read their text in front of class.

"Please read your works, listen carefully."

Students listen their friends

"Thank you, give applause"

All students gives applause to their friends

Third, the teacher does post-teaching activities, as follow:

Give conclusion about the learning.

"It's not just about friends to describe people, it can be your mother or artist. Your learning with Word Wall today has helped you practice writing and making your own content, as well as adding vocabulary and reading practice. So don't be afraid because you're still learning to be wrong." 


\section{Interview}

Based on the interview, the teacher does some steps in implementing Word Wall strategy in teaching writing descriptive text such as introducing Word Wall strategy, given words that must be categorized by each group, pasting words on the Word Wall, reading words on Word Wall with correct pronunciation and mentioning the meaning with the guidance of the teacher.

"The first steps are to introduce what the Word Wall strategy is, then what the definition is, and explain what students should do. So, first give a definition first and then when learning to learn descriptive text, so students are given the media by the teacher to attach the words. Some words are indeed provided so that students can categorize them. After grouping students, each group is given several words with different types of words. Then they discuss in the group then they must paste the words in accordance with the categories that have been provided by the teacher on the board.

This section makes students very enthusiastic because they have discussed even though there are a few wrong words but only a few. Most students can paste the words they have to categorize correctly.

Furthermore, students are asked to read one by one how to correct pronunciation with the guidance of the teacher. Besides the pronunciation, they also learn what the words mean because some of them do not know the meaning yet. Then by guiding the teacher students are asked to read together After that, students are given a quiz to mention certain words with correct pronunciation and what they mean. Then, for example, when they are finished, they return to their seats and are given other tasks based on Word Wall. Students are expected to be able to construct a complete sentence, nouns, verbs, adjectives.

The teacher also does not face difficulties in teaching descriptive text because from the experience she can saw the character of the students so that create interesting leaning.

So far, I have taught that I have not experienced difficulties, because Alhamdulillah, from our experience, we have a stock of student characters in general, so from these characters we can help as much as possible if students experience difficulties. so Alhamdulillah so far there are no difficulties ... that are not significant.

\section{Students Respond of Word Wall Strategy in Teaching Writing Descriptive Text}

Based on student interview to the students, they response were positive towards the implementation of Word Wall strategy in teaching writing descriptive text.

Table 1 . The category of students' response

\begin{tabular}{cccccccc}
\hline No & Students Response & R1 & R2 & R3 & R4 & R5 & Frequency \\
\hline 1 & Helpful in Learning & $\sqrt{ }$ & $\sqrt{ }$ & $\sqrt{ }$ & $\sqrt{ }$ & $\sqrt{ }$ & 5 \\
\hline 2 & Interesting Learning & $\sqrt{ }$ & $\sqrt{ }$ & $\sqrt{ }$ & $\sqrt{ }$ & $\sqrt{ }$ & 5 \\
\hline
\end{tabular}

The data of the research showed that all participants have the same response. Five participants have opinion that implementation of Word Wall strategy in teaching writing descriptive text are helpful in learning and interesting learning.

The teacher uses the Word Wall strategy by categorizing words that can be used in descriptive text and the Word Wall is on whiteboard in which students are easy to access and easy to see and learn, is in line with Brabham \& Villaume (2001) cited in 
(Sartika, 2017), a word wall is a collection of high-frequency sight words that are age appropriate, classified into groups or categories, and is located on the wall of classroom for children to easily see and learn.

The teacher asks students to choose some words and reading words on Word Wall with correct pronunciation and mentioning the meaning with the guidance of the teacher, is in line with Braham \& Villaume (2001) cited in (Jasmin \& Schiesl, 2009) argued that teachers may also use these words to focus on spelling rules.

The teacher give a task to write descriptive text and the students can uses some words in Word Wall, it is line with Marzano (2004) cited in (Sari \& Fahri, 2016) say that word wall strategy can give multiple purposes for students to develop their ideas in writing text, such as they can be independent in reading and writing by building their own vocabulary.

The student gives positive response to the Word Wall strategy. This strategy can help students in writing descriptive text such as vocabulary ability, kind of words, and writing manner, is in line with Mozarino (2004) cited in (Sari \& Fahri, 2016) this strategy can make the students easier to understand the context (descriptive text), mastering vocabulary, and overcome their difficulties in writing.

\section{CONCLUSION}

Implementing the Word Wall approach in teaching descriptive text writing, the investigator discovered that this approach helped learners learn how to write descriptive texts and makes exciting learning. The teacher used Word Wall in white board, which is classrooms that can be easily available during learning when learners paste phrases and are simple to see. The teacher has several methods to implement Word Wall, such as giving keywords or clues and giving each group some words to categorize that word so that learners create their thoughts in writing. Besides, the teacher also asked students to read several words with the meanings so that students know the word type and pronunciation correctly.

In implementing Word Wall strategy students give a positive response. Students revealed that Word Wall strategy helpful in learning, so that students are able to increase their writing through their ideas. In addition, the implementation of the Word Wall strategy is also as interesting learning, so that students become interested and enjoyed in learning.

Researcher has suggestions for the English teacher based on the results of this study. The teacher can make the teaching learning method as enjoyable as possible, making learners appreciate, enthusiastic and more interested in entering the learning cycle of teaching. The teacher can use Word Wall as a teaching strategy because it can assist learners to increase their writing skills and enhance their writing activity thoughts, and the teacher can use his own manner to apply it. And for the next researcher: Word Wall approach is suggested to be used to enhance their language skills in other language skills, other text genres, or another student level.

\section{REFERENCES}

Basrowi, \& Suwandi. (2008). Prosedur Penelitian Tindakan Kelas. Bogor: Ghalia Indonesia.

Jasmin, J., \& Schiesl, P. (2009). The effects of word walls and word wall activities on the reading fluency of first grade studnets. Reading Horizons, 49(4), 301-314.

Nurroni, A. (2013). Google Translate's Problems And Its Post-Editing Techniques Of An English Short Story Translation Into Bahasa Indonesia. Universitas Pendidikan Indonesia. 
http://repository.upi.edu/2997/1/S_ING_0608877_Title.pdf

Sari, N., \& Fahri. (2016). The Effectiveness Of Word Wall Strategy To Teach Writing Descriptive Text For Tenth Graders In SMA AL-AMIN Paciran. Retain, 4(2), 151158.

Sarjan, N., \& Mardiana. (2017). An Analysis On The English Teachers Strategies In Teaching Reading Comprehension at SMP 1 Of Wonomulyo. ETERNAL (English, Teaching, Learning and Research Journal), 3(2), 150-158. https://doi.org/10.24252/eternal.v32.2017.a4

Sartika, R. (2017). Implementing Word Wall Strategy in Teaching Writing Descriptive Text for Junior High School. Journal of English and Education, 5(2), 179-186. 